\title{
Physico-Chemical and Epigenetic Aspects towards Revealing Aroma Biology in Oryza Sativa L
}

\section{Anita Kumari1 ${ }^{1}$, Kumar², Anil Kumar ${ }^{1}$ and Gaur AK ${ }^{1 *}$}

${ }^{1}$ Laboratory of Bioprospecting and Metabolomics, Molecular Biology and Genetic Engineering Collage of Basic Sciences and Humanities, G.B. Pant University of Agriculture and Technology, India

${ }^{2}$ Dean, College of Agriculture, G.B. Pant University of Agriculture \& Technology, India

\section{Review Article}

Volume 3 Issue 1

Received Date: June 06, 2019

Published Date: June 27, 2019

DOI: $10.23880 /$ ggtij-16000111

*Corresponding author: Gaur AK, Laboratory of Bioprospecting and Metabolomics, Molecular Biology and Genetic Engineering Collage of Basic Sciences and Humanities, G.B. Pant University of Agriculture and Technology, Pantnagar263145, India, Email: anilgaur123@rediffmail.com

\section{Abstract}

Aroma is a complex attribute governed all the way through a complicated network of regulatory mechanisms of metabolic pathways at various levels. Abiotic factors of an environment like temperature, photoperiod and humidity seem to be more prominent signals as they influence chemical, biochemical and molecular responses. Molecular events are also important to understand the role of various proteins and nucleic acids in this complex regulation of aroma character visa vis role of structural genes/ promoters which are found either inducible or constitutive with respect to a specific macro/ micro environment. On the one side many molecules including different esters derived from lipids and or other secondary metabolites specially 2-Acetyl-1-Pyrroline (2-AP) had been reported as a major compound responsible for aroma based on organoleptic sensory evaluation test involving Human subjects providing them wide popular common food preparations.

Many plants mainly Pandanus amaryllifolius Roxb had also reported for appreciable amount of 2-AP. Oryza sativa L. had been widely accepted for the presence of 2-AP including basmati, non-basmati varieties and other scented landraces. The biogenesis of this molecule is complex. However, precursor and product relationship has been established differently. One such relationship for 2-AP had been established from plant stress related imino acid (proline) through its one of the derivative 2-hydroxy-1- pyrolline.

Although such molecules had been shown derived from carbon and nitrogen metabolism. Deletion in the betaine aldehyde dehydrogenase 2 (BADH2) gene leads in the accumulation of $\Delta^{1}$-pyrroline which reacts non-enzymatically with 


\section{Genomics \& Gene Therapy International Journal}

methylglyoxal in order to form 2-AP. Due to non-functionality of this gene which regulates the synthesis of $\gamma$-amino butyric acid (GABA), plant species synthesizing 2-AP suffers for the yield losses and susceptibility to biotic and abiotic stresses. Since, BADH2gene is under regulation differing from BADH1 gene those are coupled with 2-AP synthesis, however, BADH2 gene had been proven as a gene of metabolic diversion with reference to Oryza species. Thus, present review focus on 2-AP in relation with stress and aroma biology which in turn will help to understand the productivity and aesthetic value of rice which is a major staple food of majority of global human population.

Keywords: 2-Acetyl-1-Pyrroline (2-AP); Aroma Compounds; Betaine Aldehyde Dehydrogenase 1(BADH 1); Betaine Aldehyde Dehydrogenase 2 (BADH2); Г-Amino Butyric Acid ( $\Gamma$-GABA); Scented Landraces

\section{Introduction}

Aroma has been considered as an important trait for Human choice of food products. Food aromas are perceived in Humans by nose. The minimum threshold perception for volatiles substances in Humans is 0.007 $\mu \mathrm{g} \mathrm{L-1}$ in water according to Buttery, et al. [1] Thus, distinctive combinations of volatile components determine aroma properties of Oryza sativa L. and other food products. Oryza sativa $L$. is the member of family poaceae. Oryza sativa L. is considered as main source of nutrition and more than half the Human population is dependent on Oryza sativa [2]. It feeds more than two billion Human populations worldwide and it is the number one staple food in Asia, where it provides 40$70 \%$ of the total food calories consumed. Main Oryza sativa L. producing countries of the world are China, India, Japan, Bangladesh, Indonesia, Thailand and Myanmar.

The genus Oryza includes cultivated species 0 . sativa, which constitutes an important part of the diet of more than half of the world's population [3]. The O. sativa is the native of tropical and subtropical South-eastern Asia and Africa. It has been cultivated as a major crop for 11,500 years and sustains nearly one half of the world population. Cultivated genus Oryza has twenty one wild and two cultivated species. Out of these wild species, Nine are tetraploid and the remaining are diploid [4]. Cultivated Oryza species are: O. sativa (common rice) and O. glaberrima (African red rice). The Oryzae sativa L. is divided into three sub species namely, indica, japonica, javonica. Out of the 70,000 plant varieties known to science, about 4,000 have been identified in India [5].

Scented Oryza sativa L is considered an important commodity globally and command best prices over non- scented varieties.A large quantity of Oryza sativa L. is produced in many areas worldwide to meet the demand of consumers. In fact, scented Oryza sativa L. varieties are very popular in Southeast Asia. Recently, they have gained a wide acceptance in Europe and the USA. The demand for scented Oryza sativa L. is increasing in the local and international markets due to the better quality than the normal Oryza sativa L. Small variations in aroma can make Oryza sativa L. highly preferred and unacceptable by the consumers. Consequently, aroma and flavor have been rated as the major criteria for preference among consumers. Scented Oryza sativa is considered as an important value added commodity which accounts for best prices over non-scented varieties/ landraces.

The Indian subcontinent has basmati as 'natural gift' that has been accepted as the best scented, long and slender grain in the world markets and fetches high prices.Several genetic studies have been conducted onvarious agronomic and quality traits of Oryza sativa L. Public availability of the oryza genome sequence and mapping data on various quality traits mark important points as it has made the transfer of valuable traits to locally adopted high quality Oryza sativa L. cultivars easier and faster. The physical properties of oryza grain such as size, shape, uniformity, general appearance and its organoleptic qualities such as mouth feel, taste and aroma hold special significance because a major part of the Oryza sativa produced in the world is consumed as whole kernel and only a small fraction is converted into flour, flakes or other products.

The objectives of this study were as follows: To identify the various biochemical pathways responsible for flavor/ aroma of Oryza sativa and to understand how epigenetic (environment, cultural methods), and postharvest (e.g., drying, milling, storage, and cooking 


\section{Genomics \& Gene Therapy International Journal}

method) factors affect the aroma and flavor and to relate these effects to the numerous volatile compounds in Oryza sativa L..

\section{Epigenetic Study for Scented Oryza sativa Varieties/ Landraces}

Genetic diversity is the foundation of the genetic improvement of crops. O. sativa consists of two major varietal groups, Indica (Hsien) and Japonica (Keng) that have been recognized in China since ancient times [6-8]. Conventional scented rice varieties are classified into three isozyme groups, namely Group I (indica), Group V (indica), and Group VI (tropical japonica) [9]. These varieties were described in the table 1 .

The common rice (Oryza sativa) and the African rice (Oryza globerrima) are considered to be an example of parallel evolution in crop plants. The wild progenitor of Oryza sativa is the Asian common wild rice, Oryza rufipogon which shows a range of variation from perennial to annual types. The wild progenitor of Oryza glaberrima is perennial wild rice, Oryza longistaminate which shows variations from perennial to annual types.

\begin{tabular}{|c|c|c|c|}
\hline & Group I (indica) & Group V (indica) & Group VI (japonica) \\
\hline Varieties/ landraces & Jasmine & Basmati & Azucena \\
\hline Countries & $\begin{array}{c}\text { Thailand, Cambodia, Vietnam and } \\
\text { Southern China }\end{array}$ & $\begin{array}{c}\text { India, Myanmar, Iran, Pakistan, } \\
\text { Afghanistan, Bangladesh and China }\end{array}$ & Philippines and Indonesia \\
\hline
\end{tabular}

Table 1: Varieties/ landraces and their occurrence.

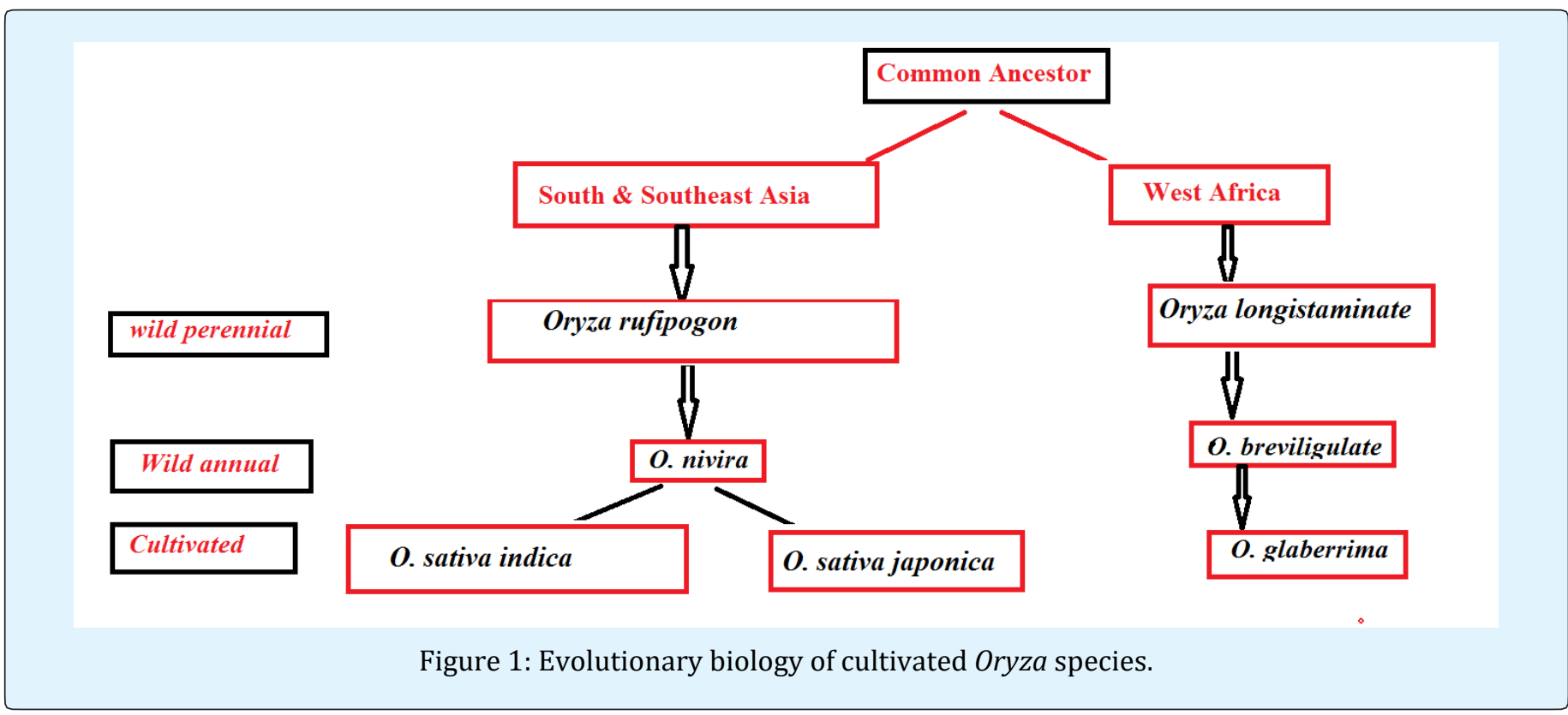

Approximately every state in India has its own varieties/ landraces of aromatic oryza sativa and specific areas for their cultivation shown in table 2 . Some of the short grain aromatic varieties/ landraces are known for their better taste, aroma and other quality trait as compared to the long grain aromatic varieties/ landraces. So efforts are needed to identify, improve and promote cultivation of such short grained aromatic Oryza sativa L. varieties for the domestic and international market. However, these short-grain aromatic varieties are susceptible to various diseases, low yielding because there is no planned breeding programme for their genetic manipulation. Attempts should be made for their proper characterization and genetic improvement to promote their production and marketing. 


\section{Genomics \& Gene Therapy International Journal}

\begin{tabular}{|c|c|c|c|}
\hline \multirow{2}{*}{ State } & \multicolumn{3}{|c|}{ Varieties / Landraces } \\
\hline & Long Grain & Medium Grain & Short grain \\
\hline $\mathrm{AP}$ & & Sumati & \\
\hline Assam & & & $\begin{array}{c}\text { Boga Tulsi, Kataribhog, Bogi Joha, } \\
\text { Bogamanikimadhuri, Kamini Joha, } \\
\text { Borjoha, Koli Joha, Borsal, Kon } \\
\text { Joha-1, Cheniguti, Kon Joha-2, Chufon, } \\
\text { Joha Bora, Boga Joha, Kaljeera, Ketaki } \\
\text { Joha, Bengoli Joha, Govindbhog, } \\
\text { Bhugui, Bhaboli Joha, Khorika Joha, } \\
\text { Bokul Joha, Kola Joha, Krishna Joha, } \\
\text { Goalporia Joha-1, Kunkuni Joha, } \\
\text { Goalporia Joha-2, Manikimadhuri Joha, } \\
\text { Ramphal Joha, Ranga Joha }\end{array}$ \\
\hline Bihar & Kasturi & \begin{tabular}{|c|} 
Gopal Bhog, Champaran \\
Basmati (Lal), Champaran \\
Basmati (Kali), Champaran \\
Basmati (Bhuri),Bhilahi \\
Basmati, Amod, Abdul, Baharni, \\
Kala Namak, Sonachur, Kesar \\
\end{tabular} & $\begin{array}{l}\text { Kamini, Badshah Bhog, Deobhog, } \\
\text { Katarni, Shyam Jeera, Kanak Jeera, } \\
\text { Kanakjeeri, Badshah Pasand,Mircha, } \\
\text { Brahmabhusi, Ramjain, Dewta Bhog, } \\
\text { Tulsi Pasand, Chenaur, Sona Lari, } \\
\text { Sataria, Tulsi Manjari, Karia Kamod, }\end{array}$ \\
\hline Chhattisgarh & & $\begin{array}{c}\text { Dubraj,Badshahbhog, } \\
\text { Tulasimanjari, Jawaphool }\end{array}$ & \\
\hline Delhi & \begin{tabular}{|c|} 
Pusa Basmati 1, Pusa Sugandh 2, \\
Pusa Sugandh 3, Pusa Sugandh 4 \\
(Pusa Basmati 1121), Pusa \\
Sugandh 5, Improved Pusa Basmati \\
1 (Pusa 1460), Pusa Basmati 6 \\
(Pusa 1401), Pusa RH 10 \\
\end{tabular} & & \\
\hline Gujarat & & GR101 & \\
\hline Haryana & Taraori Basmati, Haryana Basmati & & \\
\hline HP & & $\begin{array}{c}\text { Achhu, Begmi, Panarsa Local, } \\
\text { Kasturi, Hasan Sarai }\end{array}$ & \\
\hline J\&K & Ranbir Basmati, Saanwal Basmati & & \\
\hline Jharkhand & & Birsamati & \\
\hline Karnataka & & $\begin{array}{c}\text { Chatri, Vishnu Parag, Madhuri, } \\
\text { Mugad Sugandha }\end{array}$ & \\
\hline Kerala & & & $\begin{array}{c}\text { Jeerakasala, Gandhkasala; Medium } \\
\text { grain: Kagasali }\end{array}$ \\
\hline MP & & & $\begin{array}{c}\text { Chinore, Dubraj, Kalu Mooch, Vishnu } \\
\text { Bhog, Badshah Bhog, Tulsi Manjari, } \\
\text { Madhuri }\end{array}$ \\
\hline Maharashtra & & & $\begin{array}{l}\text { Ambemohor 152, Ambemohor 158, } \\
\text { Ambica, Indrayani, Pawana, Sakoli-7, } \\
\text { SYE-ER 1, SYE-2, Bagavati }\end{array}$ \\
\hline Manipur & & & $\begin{array}{l}\text { Ambemohor, Chinore, Medium grain: } \\
\text { Agasali, Prabhavati, Sakoli-7, Chahao } \\
\text { Amubi, Chahao Angangbi }\end{array}$ \\
\hline Orissa & & & $\begin{array}{c}\text { Kalajeera, Navapipribadhshah, } \\
\text { Navakaljeera, Ketaki Joha, Geetanjali }\end{array}$ \\
\hline Punjab & $\begin{array}{l}\text { Ranbir Basmati, Basmati 385, } \\
\text { Basmati 386, Punjab Basmati 1, } \\
\text { Super Basmati, Basmati } 217\end{array}$ & & \\
\hline
\end{tabular}




\section{Genomics \& Gene Therapy International Journal}

\begin{tabular}{|c|c|c|c|}
\hline Rajasthan & BK 79, Khushboo, Mahisugandha & & \\
\hline Tamil Nadu & & Jeeragasambha, JJ 92 & \\
\hline UP & & $\begin{array}{l}\text { Karmuhi, Kesar, Kala Namak, } \\
\text { Parsam, Sonachur, Tilak } \\
\text { Chandan, Vishnuparag }\end{array}$ & $\begin{array}{c}\text { Kala Namak-3131, Kala Namak -3119, } \\
\text { Kala Namak -620, Badshah Pasand, } \\
\text { Bhanta Phool, Bindli, } \\
\text { Chhoti Chinnawar, Jeera Battis, Kanak } \\
\text { Jeeri, Laungchoor, Adamchini, Ram } \\
\text { Bhog, Dhania, Bhantaphool, Thakur } \\
\text { Bhog, Bengal Juhi, Moongphali, Yuvraj, } \\
\text { Ramjawaien, Sakkarchini, Tinsukhia, } \\
\text { Type 3, MAUB 21 (Vallabh 21) } \\
\end{array}$ \\
\hline Uttarakhand & $\begin{array}{l}\text { Type 3, Pant Sugandh Dhan 15, } \\
\text { Pant Sugandh Dhan } 17\end{array}$ & & \\
\hline West Bengal & & Kanakchur, Katanbhog & $\begin{array}{c}\text { Badshahbhog, Chinisakkar, Danaguri, } \\
\text { Gandheshwari, Kalo Nunia, Katari Bhog } \\
\text { Radhuni Pagal, Sitabhog, } \\
\text { Tulsi Panji, Tulsi Bhog }\end{array}$ \\
\hline
\end{tabular}

Table 1: Oryza sativa L. released varieties and landraces in different states of India bearing diversified aroma.

Molecular characterization of the genotypes gives specific information about genetic diversity which helps in the development of a suitable breeding program. Characterization and quantification of genetic diversity plays important role in evolutionary biology. Information on the genetic diversity within and among closely related crop varieties is essential for a rational use of genetic resources. The analysis of genetic variation both within and among selected breeding materials is basic criteria to plant breeders. It contributes to monitoring germplasm and can also be used to predict potential genetic gains. Molecular markers play an important role to detect genetic diversity and help in the management of plant genetic resources $[10,11]$. In comparison with morphological traits, molecular markers show differences between genotypes at the molecular level and provide information about efficient tool for germplasm characterization, conservation and management. Different types of molecular markers have been used to investigate the Biodiversity of rice [9,12-19].

\section{Aroma- an Aesthetic Value and Perception}

Aroma is the major trait of scented Oryza sativa $\mathrm{L}$. which attracts consumers. This fragrance trait in Oryza sativa $\mathrm{L}$. is considered one of the most important grain quality traits, as it determines the market price. More than 100 volatile substances have been identified in fragrant Oryza sativa L. varieties, but out of these, 2acetyl-1-pyrroline (2-AP) is considered as major aroma compound responsible for aroma.Sensory properties, particularly fragrance, of Oryza sativa L. can make it highly preferred by or undesirable to consumers.
Therefore, fragrance and flavor have been considered as the major criteria for consumer's preference. Besides aroma, Scented Oryza sativa L. also contains superior nutritional values and better amino acid profiles than non-scented varieties [20].

\section{2-Acetyl-1-Pyrroline: the Fragrant Molecule}

2-Acetyl-1-Pyrroline is a major aroma substance and present in the cooked Oryza sativa L. The structure of 2APcontain a pyrroline ring and a methyl ketone group, which reacts with 2, 4-dinitrophenyl hydrazine to produce an orange-red coloured compound, 2-acetylphenyl hydrazone [2]. Molecular formula of this compound is $\mathrm{C}_{6} \mathrm{H}_{9} \mathrm{NO}$ and molecular weight of 2-AP is $111.14 \mathrm{~g} / \mathrm{mol}$. It has relatively low melting point $\left(19^{\circ} \mathrm{C}\right.$ at $760 \mathrm{~mm} \mathrm{Hg}$ ) and high boiling point value $\left(182\right.$ to $183^{\circ} \mathrm{C}$ at $760 \mathrm{~mm} \mathrm{Hg}$ ). Vapour Pressure of 2-AP is $0.793 \mathrm{~mm} / \mathrm{Hg}$ at $25^{\circ} \mathrm{C}[21]$.

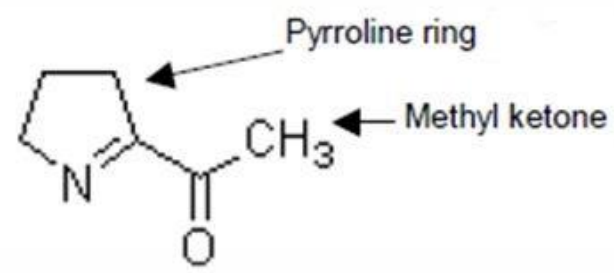

Structure of 2-Acetyl-1-Pyrroline (2-AP): 2-AP was also present in the leaves of Pandanus amaryllifolius Roxb., Bassia latifolia Roxb., spinach, taro corms, bread flowers (Vallaris glabra Ktze.), soybean, mung bean, sorghum and cucumber. 2AP was also known to be present in Bacillus cereus isolated from cocoa 


\section{Genomics \& Gene Therapy International Journal}

fermentation boxes, Lactobacillus hilgardii, and several fungal strains [2]. 2-acetyl-1-pyrroline was formed in the aerial part of scented rice from proline as the nitrogen precursor and produced at temperatures below that of thermal generation in bread baking [22].

\section{Scented Oryza Sativa L}

Scented Oryza sativa L. occupies major position in Indian Society and constitutes a small but special sub group of oryza which are considered best due to their grain quality traits. India is one of the largest exporters of Basmati in the world [23]. There are many known scented varieties (Basmati) of Oryza sativa L. from India and Pakistan and from Thailand (Jasmine).These scented varieties differ in grain length, shape, weight, density and in their cooking and eating quality. From centuries, various scented varieties/ landraces have been grown in Indian subcontinent. Scented varieties/ land races constitute different degree of aroma and based on this character, they were broadly classified as strongly, moderately and weakly scented types [24].

Aroma in scented varieties/ landraces depends on the intensity of 2-AP content and it changes with genetic and environmental conditions. Scented Oryza sativa L. possesses a characteristic odour that distinguishes it from ordinary Oryza sativa. Release of volatile substances from Oryza sativa results in odour [25]. In addition to 2-AP there were about 100 other volatile substances which are associated with the aroma development in Oryza sativa $[26,27]$.

\begin{tabular}{|c|c|c|c|c|c|c|}
\hline \multirow{3}{*}{$\begin{array}{l}\text { Sl. } \\
\text { No. }\end{array}$} & \multirow{3}{*}{ Aroma substances } & \multirow{3}{*}{$\begin{array}{l}\text { Threshold } \\
\text { limit (ppb*) }\end{array}$} & \multirow{3}{*}{$\begin{array}{l}\text { Odour descriptions } \\
\text { (Organoleptic test with } \\
\text { human subjects) }\end{array}$} & \multicolumn{2}{|c|}{ Scented } & \multirow{3}{*}{$\begin{array}{c}\text { Non-Scented } \\
\text { (ppb) }\end{array}$} \\
\hline & & & & (Jasmine) & (Basmati) & \\
\hline & & & & (ppb) & (ppb) & \\
\hline 1. & Hexanal & 5 & Green, grass & 853 & 751 & 1960 \\
\hline 2. & Butanol & 500 & Medicinal & 5 & 1 & 9 \\
\hline 3. & Hexane-2-one & 140 & Fruit, Spicy & 23 & 22 & 40 \\
\hline 4. & Heptanal & 3 & Fruit, Fatty & 25 & 34 & 26 \\
\hline 5. & hex-2-enl & 17 & Green, fruity & 7 & 5 & 15 \\
\hline 6. & 2-pentylfuran & - & Nutty, beany & 35 & 21 & 78 \\
\hline 7. & Pentane-1-ol & 4000 & Sweet, strong & 89 & 139 & 104 \\
\hline 8. & Octanol & 0.7 & Citrus, fatty & 26 & 40 & 29 \\
\hline 9. & hept-2-enol & 13 & Fatty, green & 45 & 44 & 80 \\
\hline 10. & 2-acetyl-1-pyrroline & 0.1 & Sweet, popcorn & 49 & 7 & 3 \\
\hline 11. & $\begin{array}{l}\text { 6-methylhept-2-en-2- } \\
\text { one }\end{array}$ & 50 & Herby, green & 11 & 3 & 3 \\
\hline 12. & Henan-1-ol & 25000 & Sweet, green & 51 & 45 & 59 \\
\hline 13. & Nonanol & 1 & Floral, fatty & 28 & 25 & 42 \\
\hline 14. & Oct-2-enol & 3 & Green, herby & 47 & 27 & 95 \\
\hline 15. & Oct-1-en-3-ol & 1 & Herby, earthy & 34 & 25 & 58 \\
\hline 16. & 2-Ethyl hexanol & - & Oily, sweet & 0 & - & 44 \\
\hline 17. & Benzaldehyde & 350 & Nutty, sweet & 36 & 27 & 49 \\
\hline 18. & Non-2-enol & 0.08 & Fatty, waxy & 14 & 6 & 28 \\
\hline 19. & Dec-2-enol & 0.4 & Fatty, green & 11 & 9 & 15 \\
\hline 20. & deca-2,4-dienal & 0.07 & Fatty, citrus, strong & 13 & 8 & 31 \\
\hline 21. & 4-vinylguaical & 3 & Spicy, fruity & 15 & 23 & 42 \\
\hline 22. & Indole & 140 & Faecal, floral & 12 & 3 & 17 \\
\hline
\end{tabular}

*ppb- parts per billion

Table 2: Threshold limit, odour descriptions and concentrations of majorityvolatile aroma substances in scented and non-scented Oryza sativa L.Wilkie, et al. [50].

Genetic basis of fragrance in Oryza sativa L. lead to the identification of a single locus on chromosome 8 (fgr) associated with fragrance. BADH2 protein catalyzes the oxidation of $\gamma$-Amino Butyraldehyde, so that a non- functional allele results in the accumulation of both $\mathrm{AB}$ ald and its cyclic form, pyrroline, resulting in enhanced 2AP synthesis [8]. 


\section{Genomics \& Gene Therapy International Journal}

\section{Nucleic Acids Sequence Determination for Aroma: a Complex Qualitative Trait}

Information on the genetic makeup of Oryza sativa L. shall facilitate breeding strategies for selection of new high yielding scented/ aroma bearing Oryza sativa L .landraces/varieties along with superior quality and quantity. In India, breeders have evolved cross-bred Basmati varieties using conventional hybridization and selection methods. Most of the quality traits in Oryza sativa $\mathrm{L}$. are polygenic with complex inheritance pattern which is highly influenced by environmental factors [28]. Initially, it was reported that aroma is controlled by a single dominant gene with a segregation ratio of 3:1 [29]. Subsequently, Jodon E [30] disagree with this observation and reported that aroma is controlled by a single recessive gene, fgr. Using a biparental population hypothesis derived from a cross between Pusa 1121 and Pusa 1342, it was revealed that aroma is controlled by three Quantitative Trait Loci (QTLs), aro3.1, aro4.1 and aro8.

These are located on short arm of chromosome 3and long arms of chromosome 4 and 8, respectively [31]. The major aroma QTL (aro8.1) was identified on chromosome 8 with logarithm of the odds to the base 10 (LOD) score of 11.54 between SSR markers RM223 and RM80 and explained the phenotypic variation for aroma in Oryza sativa L. Later on, studies by researchers Bradbury, et al. [32], Wanchana, et al, [33], Chen, et al. [34] identified badh2 (recessive allele) as a candidate gene for aroma on chromosome 8, which codes for enzyme betaine aldehyde dehydrogenase (BADH). This enzyme (BADH) is involved in the synthesis of glycine betaine which is an osmo protectant against salt and drought stress in a large number of species. Oryza sativa L. does not accumulate glycine betaine but it has two functional genes coding for the BADH enzymes. Most of the aroma bearing Oryza sativa $\mathrm{L}$. varieties from different isozymes forms share the same 8 bp deletion in intron 7 of BADH2gene for which Amarawathi, et al. [31] designed a perfect gel based marker (nksbadh2) that discriminates between aroma and non-aroma varieties. The BADH1gene located on chromosome4, also play role in aroma expression in Oryza sativa L. [35]. The QTL aro3.1 on chromosome 3 was mapped in marker interval RM5474-RM282 with LOD score 3.20 , explaining $10.3 \%$ of the phenotypic variation, whereas QTL aro4.1was located in the marker interval RM5633-RM273 on chromosome 4 with LOD score of 3.30 , explaining $6.1 \%$ of phenotypic variation.

Metabolic Pathways for 2-Ap Genesis
Several research findings led to the assumption that 2$\mathrm{AP}$ is a resultant of the Maillard reaction and it is formed during the cooking or processing of Oryza sativa L. and other food products. Scented Oryza sativa L. release this aroma in fields at the time of harvesting, milling, cooking and eating conferred that Della variety contained higher amount of 2-APas compared to Thai variety jasmine. Berner and Hoff, [36] also concluded that the single recessive gene present on chromosome 8 , control the aromatic nature on Della variety. This single recessive gene was determined by RFLP technology according to Ahn, et al. [37].

Sequencing of Oryza sativa L. genome was done and physical fine mapping shown that betaine aldehyde dehydrogenase (BADH2) present on chromosome 8 is responsible for formation of 2-AP scented Oryza sativa L. According to them eight base pair deletion in BADH2 gene leads to the formation of premature stop codon. This produces non-functional protein and synthesizes 2AP.Since then focus area for several researchers has been to introduce the fragrance trait in non-scented Oryza sativa $\mathrm{L}$. and other important crops. Buttery, et al. [32] suggested that the difference between aromatic and nonaromatic Oryza sativa L. was not the presence and absence of the 2-AP but the difference in the quantity of the chemical in the grain. Multiple alleles of scented oryza produce different aroma intensities by slight change in the enzyme. According to glycine betaine synthesis pathway, BADH gene oxidizes betain aldehyde but this glycine betaine has not been synthesized in oryza [38,39]. BADH2 has higher affinity for 4-aminobutyraldehyde than for betaine aldehyde and oxidize 4-aminobutyraldehydeto g-aminobutyric acid (GABA) [40-42].

In Bacillus cereus, 81 -pyrroline is the precursor of 2$\mathrm{AP}$ and exist in equilibrium with, 4-aminobutyraldehyde [43]. Thus, it was concluded thatBADH2 participates in the pathway of GABA synthesis by oxidizing 4aminobutyraldehyde, produced from putrescine, to GABA. However, varieties carrying BADH2 cannot carry out the oxidation step, and accumulate both 4aminobutyraldehyde and D1-pyrroline, thus activating the pathway of 2AP synthesis. According to Huang, et al. [44] study, D1-pyrroline-5-carboxylate (P-5-C) reacts directly with methyl glyoxal to form 2-AP. P-5-C is the precursor of proline synthesized from glutamate. Chemical analysis of a wide range of Oryza sativa L. has revealed many compounds that differ in concentration between fragrant and non-fragrant Oryza sativa L. varieties $[45,46]$. 


\section{Genomics \& Gene Therapy International Journal}

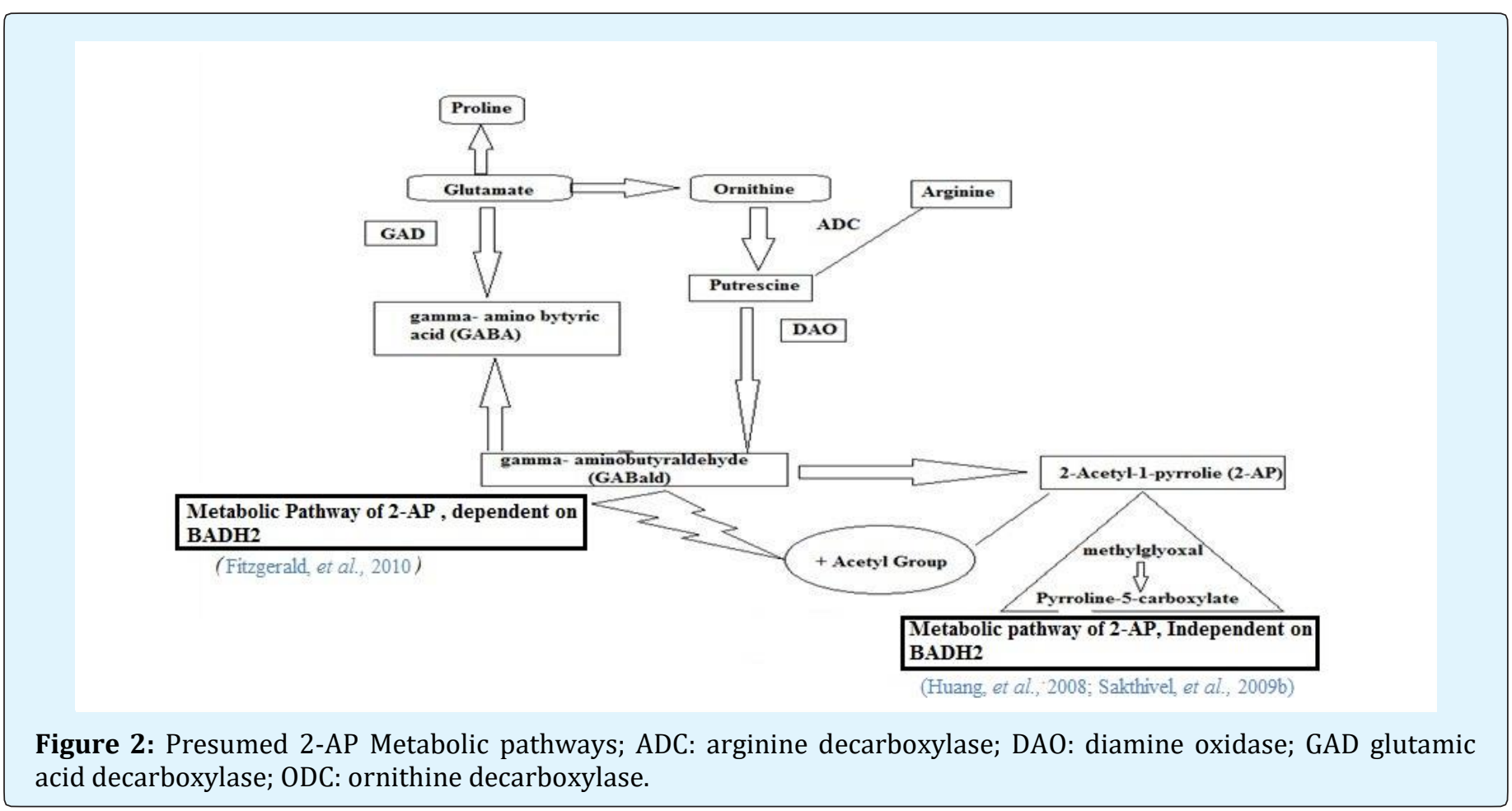

The aromatic compound, 2-acetyl-1-pyrroline (2AP) was discovered in Oryza sativa L. in 1983.Using a combination of sensory panels and gas chromatogram techniques Buttery, et al. [47] \& Buttery et al. [48] determined 2-acetyl-1-pyrroline (2-AP), is a potent flavour component with a lower odour threshold that gives both Basmati and Jasmine their distinctive fragrance.2-AP is associated with pleasant, popcorn like fragrance of scented Oryza sativa L. It is found in all parts of plants of fragrant varieties except for the roots. Basmati grains contain 0.09 parts per million of 2-AP which is about 12 times more concentration than un-scented Oryza sativa $\mathrm{L}$. varieties. Concentration of 2-AP in non-scented is 10 to 100 times lower than that of scented Oryza sativa L. varieties [46,49]. Scented Oryza sativa L. has 2-AP concentrations from about 3000 times, while non-scented has concentrations of 2-AP of only about 30 times this threshold level of 2-AP in water [50].

Methods of determining the level of 2AP by using gas chromatography, have been developed [51,52]. But, these methods often require large tissue samples and are expensive, time consuming and the peak corresponding to 2-AP is small compared to the peaks corresponding to other chemicals present in Oryza sativa L., making the results difficult to interpret.

\section{Biology of Aroma Genesis}

BADH2 is mainly involved in synthesis of glycine betaine from betaine aldehyde, Livingstone, et al. [53]. But oryza is a non-accumulator of glycine betaine. Bradbury, et al. [41] found that BADH2 has higher activity towards gamma-aminobutyraldehyde. (GABald) and moderate activity on betaine aldehyde. BADH2 regulate the metabolism of gamma-amino butyric acid $(\gamma$-GABA) from GABald in oryza. GABAld spontaneously cyclises to $\Delta 1$-pyrroline (precursor of 2-AP).This was recently confirmed by the absence of 2-AP in an aromatic variety after transformation with functional BADH2 Chen, et al. [40] and suppression of BADH2 transcript in a nonaromatic japonica callus (Oryza. sativa japonica cv. Nipponbare) increases 2-AP level, Vanavichit, et al. [42]. According to Yoshihashi, et al. [22], L-proline is considered as the precursor in the production of 2-AP in rice plants.

The immediate precursor of 2-AP was found to be 1pyrroline (1P) which is formed from 4aminobutyraldehyde (AB-ald; the immediate precursor of 4-aminobutyric acid (GABA) Vanavichit, et al. [42]. According to Bradbury, et al. [41], Chen, et al. [40] accumulation of 2-AP in Oryza sativa L.is due to the absence of BADH2 activity, leading to an increased level of 


\section{Genomics \& Gene Therapy International Journal}

its substrate, GABald/D1-pyrroline. Availability of free GABald/ $\Delta$ 1-pyrroline has been observed to be the rate controlling factor in synthesis of 2AP. The availability of GABald/ $\Delta 1$-pyrroline, is dependent on degradation of polyamines and proline and the activity of BADH2 enzyme. Utilization of GABald/ $\triangle 1$-pyrroline by BADH2 for conversion to GABA inhibits $2 \mathrm{AP}$ synthesis, whereas, accumulation of GABald/ $\Delta 1$-pyrroline results in increased $2 \mathrm{AP}$ synthesis. In non-scented rice, functional BADH2 enzyme inhibit the synthesis of $2 \mathrm{AP}$ by converting $\mathrm{AB}$-ald to $\gamma$-GABA but in case of scented varieties of Oryza sativa L., non-functional BADH2 accumulates AB-ald and leads to the formation of $2 \mathrm{AP}$.

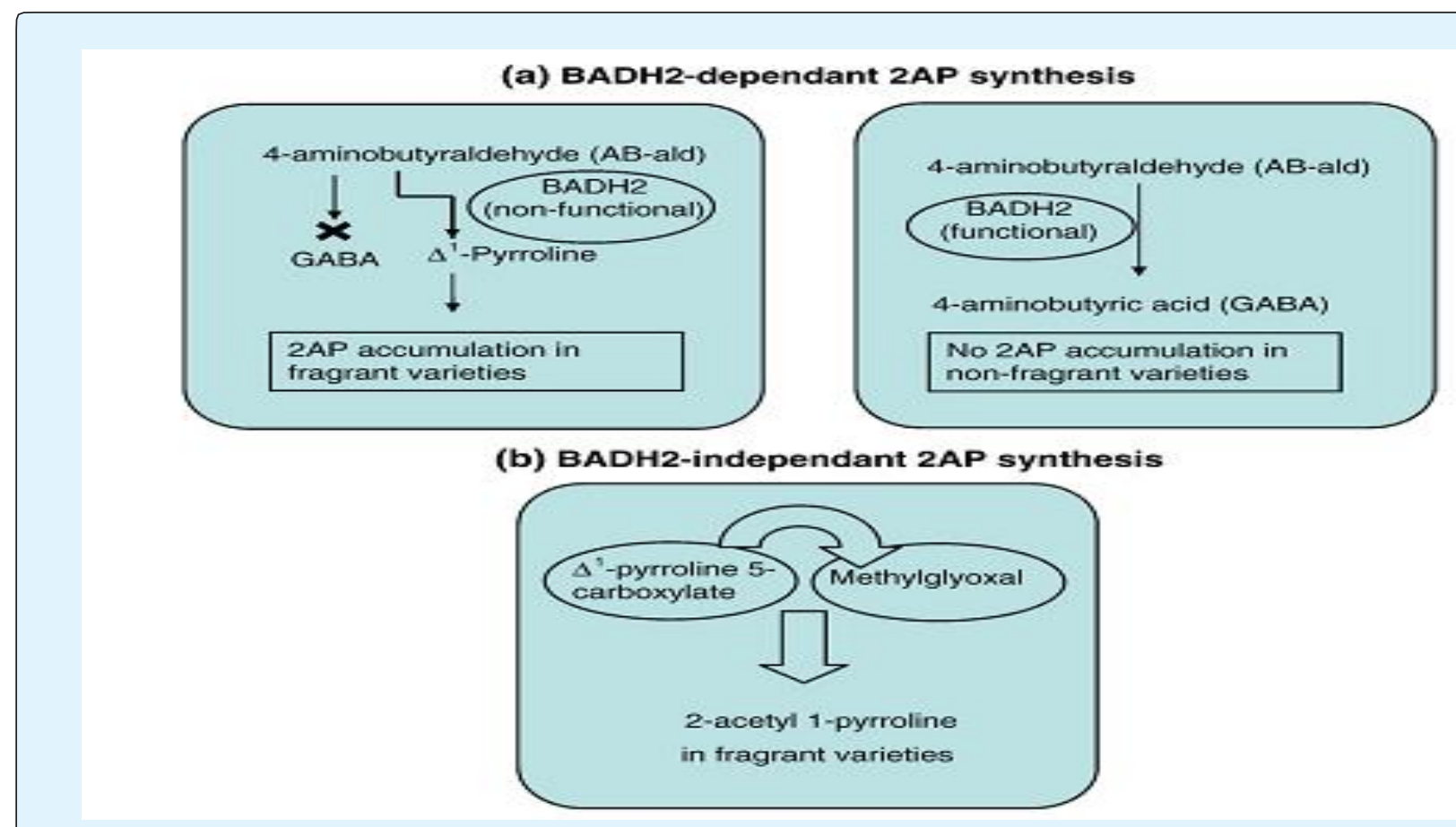

Figure 3: Metabolic Pathways of 2-APin Oryza sativa L. (a) BADH2 dependent [40,41]; (b) BADH2 independent [44].

\section{Possible Metabolic Pathways for Aroma Genesis}

The other important compounds implicated with fragrance trait were alkanals, alk-2-enals, alka-2,4dienals, 2-pentylfuran and 2-phenylethanol. Widjaja, et al. [49] identified that other compound to contribute to the total aroma profile. Jezussek, et al. [10] identified 2-amino acetophenone and 3-hydroxy-4,5-dimethyl-2(5H)furanone which is present in high amount in Basmati 370. More recently, Chen, et al. [40], while reporting the volatile chemistry of Black rice, (aromatic specialty rice popular in Asia) observed that guaiacol, indole, and $\mathrm{p}$ xylene, in addition to 2AP, were found largely responsible for its unique flavor.

Different pathways have been used for the chemical synthesis of 2-AP by different researchers as shown in
Figure 4 [54-56,43]. According to De Kimpe, et al. [57], the first reaction in the synthesis of 2-AP involves conversion of pyrrolidine into tripyrroline, followed by hydrocyanation of the tripyrroline into 2cyanopyrrolidine, then its oxidation into 2-cyano-1pyrroline, and finally Grignard addition of methyl magnesium iodide, affording an overall yield of $16-19 \%$ from pyrrolidine. The synthesis of 2-AP has also been achieved at the Agricultural Chemicals Division of IARI, New Delhi by modifying the method of Duby and Huynh$\mathrm{Ba},[58]$. The modified method leads to synthesis of 2(ethoxy-1-ethenyl)-1 pyrroline, a precursor of 2-AP, which is a much more stable compound and can be easily converted into to 2-AP by hydrolysing it using hydrochloric acid and further neutralization with sodium hydroxide. 


\section{Genomics \& Gene Therapy International Journal}

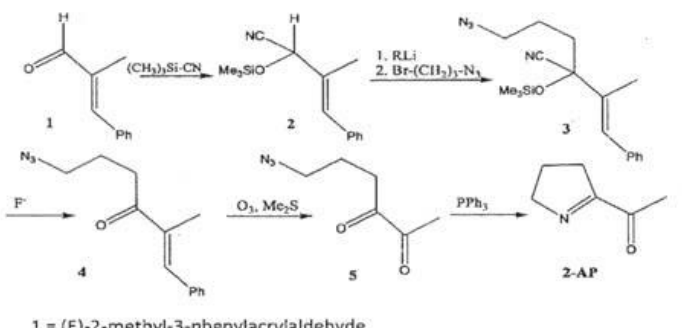

$1=(E)-2-$ methyl-3-phenylacrylaldehyde

$2=$ nitrile derivative

$3=$ azide derivative

$4=(E)-6$-azido-2-methyl-1-phenylhex-1-en-3-one

$5=6$-azidohexane-2,3-dione
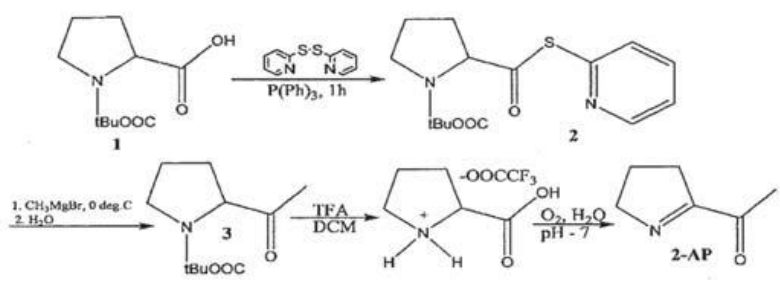

$1=$ Boc-Proline

$2=$ Thio ester of 1

$3=$ BOC-Pyrrolidine
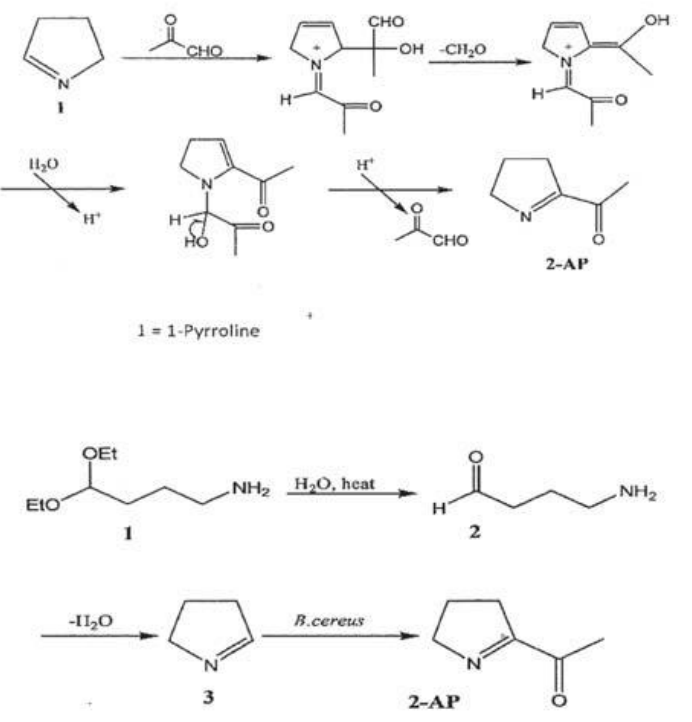

$1=4,4-$ diethoxybutan-1-amine $2=4$-aminobutanal $3=1$-Pyrroline

Figure 4: Different routes for Synthetic 2-AP (a) Rewicki, et al. [54] (b) Schieberle [55] (c) Hofmann \& Schieberle [56] \& (d) An Adams and Robert de Kimpe [43].

\section{Genomic Studies Pertaining to AROMA}

It is particularly difficult for the breeders to select genotypes with desirable quality attributes using conventional breeding methods due to lack of separate phenotypic classes in the progeny and also tedious methodologies for quality testing often requiring large amount of seeds. Molecular marker is a fragment of DNA that is associated with a certain location within the genome that follow predictable segregation pattern and show association with observable phenotypic variations. Molecular markers such as SSR, SNP and AFLP and various softwares have been used extensively to identify QTLs and to locate important genes for various quality traits of oryza sativa [59-62].

\begin{tabular}{|c|c|c|c|c|}
\hline \multirow{2}{*}{$\begin{array}{c}\text { Genes/ } \\
\text { Promoters }\end{array}$} & \multirow{2}{*}{$\begin{array}{c}\text { Chromosome } \\
\text { no. of Oryza } \\
\text { sativa L. }\end{array}$} & \multicolumn{2}{|c|}{ Primer sequence } & \multirow{2}{*}{$\begin{array}{c}\text { Expression } \\
\text { product }\end{array}$} \\
\hline & & Forward & Reverse & \\
\hline \multirow{2}{*}{ BADH2 } & \multirow{2}{*}{8} & TTGTTTGGAGCTTGCTGATG & AGTGCTTTACAAAGTCCCGC & ESP, EAP \\
\hline & & CTGGTAAAAAGATTATGGCTTCA & CATAGGAGCAGCTGAAATATATACC & INSP, IFAP \\
\hline BADH2 & 8 & GGTTGCATTTACTGGGAGTTA & GTTTGTTTCCAAATTTCTGTGGA & nksbad2 \\
\hline \multirow{3}{*}{ BADH2 } & \multirow{3}{*}{8} & CCTCTGCTTCTGCCTCTGAT & GATTGCGCGGAGGTACTTG & FMbadh2-E2A \\
\hline & & CTTCTGCCTCTGATTAGCCT & GCCGTGAGCCATATACACTT & FMbadh2-E2B \\
\hline & & GGTTGCATTTACTGGGAGTT & CAGTGAAACAGGCTGTCAAG & FMbadh2-E7 \\
\hline \multirow{3}{*}{ fgr } & \multirow{3}{*}{8} & AACTGTTGGATCGACAAGACCTTCC & ACGGCGTTAAGCTAGACAGACAGAGC & RM23120 \\
\hline & & ATGGACTTTCGAGAATGTTG & GAGTACGAAATGAAGGCAAG & RM3459 \\
\hline & & ATTTGCCTCCTGAGTCTG & GAGGATGGGGAAGATAAA & Aro7 \\
\hline \multirow{2}{*}{ Qaro3-1 } & \multirow[b]{2}{*}{3} & AAGTGTTGGTGAGCATAGC & TTTGTGTTTGGAGAGACGAG & RM5474 \\
\hline & & CTGTGTCGAAAGGCTGCAC & CAGTCCTGTGTTGCAGCAAG & RM282 \\
\hline
\end{tabular}

Table 3: Molecular markers sequence determination using satellite DNA for Oryza sativa L. aroma related sequence identification for their use in marker-assisted selection. 


\section{Genomics \& Gene Therapy International Journal}

Application of mapped SSR markers in rice breeding also provides insight as to which chromosomal segments have been introgressed from specific parental genomes [28]. Aroma trait in oryza sativa was initially reported to be controlled by a single recessive gene (fgr) that mapped on chromosome8, at a genetic distance of $4.5 \mathrm{cM}$ from the RFLP marker RG28 [37]. Rice microsatellite (SSR) markers RM33 andRM85 were mapped genetically between the probes RG28 and RG1 flanking the genomic region containing the fgr gene [63]. Several SSR markers and a SNP marker linked to the fgr locus have been developed for distinguishing the fragrant varieties from the non-fragrant one [64,32]. Some PCR based markers used for marker-assisted selection using simple agarose gel electrophoresis are listed in table 4.

\section{Transcriptome Studies Pertaining to Aroma}

Identification of genes underlying various quantitative traits is important for the development of functional markers that can be used in marker-assisted plant breeding. Map-based cloning approach has long been used for gene identification but is a time consuming and expensive tool [65]. In recent times, microarray based expression profiling of genes also known as transcriptome profiling has been an important tool for gene identification. The availability of whole genome microarray chips of various organisms has paved the way for the effective study of complex traits, by assessing the expression of almost all the genes at a time [66].

The possible involvement of other genes/alleles responsible for grain aroma cannot be ruled out as some aromatic rice varieties lacking badh2 gene have been reported [67]. Being a complex inherited trait, limited information is available about aroma genes other than badh2, so the present investigation was done to screen out genes co-located in the aroma QTL regions, with major focus on chromosomes 3 and 4. Our earlier reported data on the mapped QTLs for basmati grain aroma were taken as the basis for this further investigation [31]. RILs with similar phenotype were pooled to create bulks which significantly reduced the number of samples to be analyzed and their transcriptome profiles were generated through microarray.

\section{Response of Fertigation Practices During Cultivation of Oryza Sativa L. on Aroma Genesis}

The quantity of aroma in rice is affected by both genetic and environmental elements $[68,69]$. Scented rice grown in areas where temperature is cooler at the time of maturity best develops fragrance. Fragrance is mainly controlled by major gene, but the environmental conditions and cultivation practices could easily influence the intensity of fragrance or concentration of 2-AP in rice. Pusa basmati rice contains no 2 AP during summer but when grown in rainy weather contained $0.030 \mathrm{ppm} 2$-AP [70]. But according to Bradbury et al. [32], plants exposed to water stress has higher level of 2 AP. Extraction procedures for quantification of 2-AP, cooking practices and soil type also influence the concentration of 2-AP [71].

Environmental impacts such as salt stress, drought and temperature, duration and conditions of storage, the harvest timing the level of milling [72,40], and the flowering time [70]. Concentration of 2-AP in oryza sativa is affected by the cultivar, temperature conditions, other climatic conditions such as available sunlight, and other agricultural practices. 2-AP is produced in the aromatic oryza sativa at a temperature only lower than that of thermal generation in bread-baking [22]. Itani, et al. [72] studied the influence of harvest time and temperature during ripening on the concentration of 2-AP in several samples of brown rice grains from the Hieri cultivar produced during a period of 3 years in the Kubokawa area of Kochi Prefecture, Japan. Many of the samples had similar values of 2-AP however, in a few samples, compared to the individual year averages of $100 \%$, extremely high $(200 \%)$ or low $(60 \%)$ concentrations of 2AP were observed. In 2 specific varieties of brown rice, Miyakaori (an early-heading cultivar) and Hieri, (lateheading cultivar), the concentrations of 2-AP reached maximum levels during 4 weeks after heading.

However, in cultivar Miyakaori, the concentration decreased rapidly to a maximum of $20 \%$ at 8 weeks after heading, whereas in cultivar Hieri, the maximum concentration after 8 weeks was $40 \%$. The 2 -AP concentration differed with cultivars and temperature of ripening. Brown rice, which ripened at a lower temperature, had higher 2-AP concentration than the rice ripened at a higher temperature, in the case of long-grain cultivar 'Sari Queen' as well as the short-grain cultivar Hieri [72]. Extent of exposure to solar radiation also affects the rate of accumulation of 2-AP in rice cultivars. Shading treatments applied in the case of 2 Chinese aromatic rice varieties (Yuxiangyouzhan and Nongxiang 18) led to higher accumulation of 2-AP and also other associated compounds.

Different plant hormones and growth regulators, including gibberellic acid (GA) and 3-indole acetic acid 


\section{Genomics \& Gene Therapy International Journal}

(3IAA), are necessary for the proper development of the plants. Application of insecticides, fungicides, and other pesticides is a common agricultural practice. However, there is very little known about the effects of these chemicals on the different physicochemical attributes of the plants and their biological products. GA, 3IAA, paclobutrazol, and the regulator mixture applied during different stages of growth were observed to have an adverse influence on 2-AP concentrations in both brown and milled rice [73]. In the case of the study of 2 cultivars, averages observed over treatments showed the lowest mean 2-AP concentrations of 1.95, 1.90, and $1.89 \mu \mathrm{g} / \mathrm{g}$, respectively, in Guixiangzhan. In the Peizaruan xiang variety, GA treatment decreased the content of 2-AP by $32 \%$, 3IAA decreased by $21 \%$, paclobutrazol decreased by $30 \%$, and the regulator mixture decreased the 2-AP content by $47 \%$ as compared to the control.

Rice cultivar and growth hormone treatment had significant effects on 2-AP content. Interaction effects of season with cultivar and season with treatment were also significant. Decline in the levels of 2-AP reported after growth regulator treatments was explained by (a) side activities Accepted Manuscript 14 of growth regulators on enzymes involved in the synthesis of 2-AP and (b) the modification of their transport mechanisms. Hence, decreases in 2-AP concentration due to growth regulators was attributed to activation of BADH2 and reduced activity of enzymes involved in proline synthesis from glutamine, including glutamine synthetase, glutamate synthase, and P5CS, in the case of foliar application of growth regulators [73]. However, these observations should be further investigated for substantiation.

\section{Metabolome Studies Pertaining to Aroma}

Although genomics approaches have helped to identify and characterize several genes that determine important grain quality traits, we also try to understand the regulatory and metabolic pathways that are involved in aroma related expression products which are responsible for aroma biology.

\section{Bioseparation and Bioanalytics for Aroma Bearing Major Volatile Substances and Non- Volatile as Well}

Tools and techniques involved for the extraction of aroma substances required collection of materials from different regimes of their habitats, concentration of these substances for their analysis based on the need of specific environment where sophisticated instrumentation are situated for bio separation and their quantification.
Conventional protocols for the extraction are steam distillation/ solvent extraction. Presently, profiling of various substances from Oryza sativa $\mathrm{L}$. had been performed commonly through gas chromatography (GC) using various detectors and as a matter of fact flame ionisation detector is a conventional detector. Mass spectroscopy (MS) / tandem MS presently being utilized for profiling of substances with the application of various kind of software's from different available chemical libraries based on spectral analysis. Olfactometry had been reported by Zeng, et al. [74].Size of different substances to be analysed for GC had been found independent towards their impact on aroma substances analysis [52].

Several methods have been developed for the detection of aroma compounds in different rice genotypes, both, quantitatively and qualitatively [47,75]. The majority of studies which have focused on the genetics of fragrance in rice determined fragrance are due to a single recessive gene [76,77]. Some methods measured varying degrees of fragrance using sensory panellists scaling fragrance, usually on a scale of one to ten [36] while others used a combination of sensory panelists and gas chromatographic methods to measure the level of 2AP in plant samples, while other methods used a simple binary system of fragrant/non-fragrant, to categorize the fragrance phenotype [75,77]. At present, for evaluation of aroma in seeds and leaf tissue by reacting with Potassium hydroxide has been still used as a convenient and appropriate method [78]. Sensory evaluation of rice fragrance showed a strong correlation with the concentration of 2-AP. The concentration of 2-AP was analyzed by gas chromatography - flame ionization detector (GC-FID) [46] or gas chromatography - mass spectrometry (GC-MS) [79]. Yoshihashi, et al. [22] used stable isotope dilution with GC-MS selected ion monitoring to quantify the amount of 2-acetyl-1pyrroline. Analysis of volatile componentsby solid phase micro-extraction (SPME) fibres in combination with GC/MS has proven to be an efficient method [80]. SPME has been reported as a successful tool for screening but not for the quantification of 2-acetyl-1-pyrroline in fragrant rice varieties [81].

\section{Integration of Various Analyses at Different Levels Toward Aroma Biology in Oryza Sativa L. Systems}

Present century informatics tools have been providing opportunities for identification of all genes and their expression products Weckwerth, et al. [82]. Technologies for high-throughput analysis for sequencing and 


\section{Genomics \& Gene Therapy International Journal}

expression products have been advancing tremendously. Functional genomics challenges are ahead. Metabolome analysis for various metabolites paving the way due to its unique and the most importance in various field including food and agriculture, medicine, cosmetics etc. Many such reports for metabolite analyses are appearing in various research articles; Oksman-Caldentey, et al. [83], Mendes, et al. [84], German, et al. [85]. Complex metabolite (exo/endo) from plants had been reported by Tiller, et al. [86], Oliver, et al. [87], Villas Boas, et al. [88], Zamboni, et al. [89]. Metabolome analyses are driven primarily by recent advances in NMR and mass spectrometry towards achieving goals of functional genomics research according to Brocke, et al. [90], Dettmer, et al. [91], Katajamaa, et al. [92]., Integrated strategic approach for optimal sample extraction, metabolite separation, their detection, automated data gathering for the ultimate goal of their quantification had been emphasized Van Beek, et al. [93].

Enormous diversity of chemicals produced by plant is due to the different functions of the genes of their genomes Tohge, et al, [94]. Metabolomics is the promising field of post genomic research Saito, et al. [95]. A metabolome represents the important phenotype of cells deduced by perturbation of gene expression and the modulation of protein functions Schauer, et al. [96], Schwab, et al. [97]. In addition, the metabolome can also influence gene expression and protein function Maury, et al. [98], Warner, et al. [99], Hirai, et al. [100]. Therefore metabolomics plays a key role in understanding cellular system and decoding the functions of genes Schauer, et al. [96], Saito, et al. [101]. The large variations in the relative concentrations of metabolites also make metabolite analysis more complicated. Therefore, comprehensive coverage can only be achieved by using multi-parallel complementary extraction and detection technologies with careful experimental design Saito K, et al. [95]. Currently, there is no single technology available to detect all the compounds in single analysis in any plants or other organisms Fernie, et al. [102], Hall, et al. [103]. For this purpose, combination of multiple analytical techniques, such as gas chromatography, liquid chromatography, capillary electrophoresis (CE)-MS, NMR, and rapid scanning timeof-flight (TOF) are generally used to detect maximum compounds $[91,104,105]$.

Metabolites can be extracted from milligram of tissues either in polar/semipolar (e.g. methanol/water or ethanol/water) or non-polar (e.g. chloroform) solvent. In case of GC-MS (gas chromatography-mass spectroscopy) method, a two steps derivatization by methoxyamination and trimethylsilylation represent key techniques for profiling of hydrophilic metabolites Lisec, et al. [106].

Metabolite signals in row chromatogram/spectrum data need to detect and quantify carefully. These data need to assign with metabolite information to produce a data matrix listing a metabolite and its intensity data. The peak picking process which was a technical bottleneck in the early stage of metabolomics study can now be performed routinely by developing a series of software dealing with GC, LC-MS, CE, and NMR data in which matrices containing intensity values of all signals in sample are taken into consideration $[107,108]$.

Determination of metabolites in complex plant tissues and dissemination of metabolomics research data needs development of improved technology tools and techniques [109-113].

Model can be used for prediction and generation of hypothesis Sumner, et al. [114]. For understanding of complex metabolic pathways, mathematical models are considered as powerful technique Morgan, et al. [115], Gombert, et al. [116], in order to modify the distribution of metabolic flux or to rationally design metabolic pathway for new product according to Bailey, et al. [117]. For quantification of metabolic fluxes in dynamic metabolic system, Transient isotopic flux analysis and kinetic modeling are used [115]. These tools are frequently used to concentrate on metabolic flux response to environmental and genetic perturbations in plant metabolism. Continuous development in isotopic and kinetic modeling, quantifying metabolite exchange between compartments, and transcriptional and post transcriptional regulatory mechanism governing enzyme level and activity will enable simulation of large sections of plant metabolism under no-steady state conditions [118]

Data acquisition for specific chemical substances from different biological systems, their transformations, validation and annotation have to be taken into consideration for their mining with different tools applicable to analytes from various biological systems. Facilitating such data model development would be possible through various kinds of approaches of integrating researchers from different disciplines. In order to decipher biological relevance of each metabolite after their analyses shall be comprehensive. Bioinformatics shall enable better understanding towards aroma biology. 


\section{Genomics \& Gene Therapy International Journal}

\section{Conclusion}

Fragrances of Oryza sativa L. have been popular and attractive among Human population consuming for the diet. Aroma qualitative traits are now recognised for breeding strategies in the Oryza sativa L. germplasm. Though 2-AP is a relatively more prominent fragrant substance among other substances responsible for different aroma in Oryza sativa L., a range of substances including majority of volatiles and non-volatiles as well. Possibly 2-AP is associated with every aroma in its own unique way. However, information is available about the different compositions of these substances with diverse aroma/ scent. Satellite DNA markers for different molecular analysis for genomic studies at present are being in practice as a promising approach toward exploring major qualitative traits for aroma. Thus, it seems to be essential for Oryza sativa L. genetic makeup in order to develop better modifications in the genome through nucleic acid sequence alterations strategies to achieve an accepted material for Human consumption. Nevertheless, there are some ambiguous issues related with the genetic base of fragrance as a matter of fact that secondary metabolites are under strict control of various elicitors in a particular environment and need to understand before pathway engineering to safeguard biodiversity in one hand and their efficient utility for Human demand on other hand [119]. Consequently, identifying important genes structural and regulatory as well underlying diverse fragrances seemingly looking troublesome with aroma trait. However, due to tremendous advances in the genomics shall make possible in near future to entirely revealing aroma biology. Further progresses in metabolomics and investigation of the expression levels of differentially regulated nucleic acids/ amino acids sequences shall pave the way to understand complexity of molecular mechanisms associated with fragrance related sequences both at protein and nucleic acid data base which shall pave the way to enhance understanding of perceptive molecule 2-AP in food commodities during biological evolution with special reference to the effective aroma/ scented Oryza sativa L.

\section{Author Contribution}

$\mathrm{AK}$ and $\mathrm{AKG}$ conceptualized and wrote the manuscript. While JK and AK contributed critically in administering and coordinating the material.

\section{Acknowledgement}

We wish to acknowledge Dr. U. S. Singh, Professor and Principal Investigator (PI) Department of Plant Pathology
College of Agriculture, G.B. Pant University of Agriculture and Technology, Pantnagar-263145, India, Dr. Dharmendra Khokhar, SRF and Dr. DC Pathak, JRF Programme Mode Support (PMS) Phase-I in Agricultural Biotechnology, Department of Biotechnology(DBT), Ministry of Science and Technology, New Delhi, Government of India, Dr. I. D. Pandey, Professor \& CoProject Investigator(PI), Department of Genetics and Plant Breeding, College of Agriculture, G.B. Pant University of Agriculture and Technology, Pantnagar263145, India, Dr. Manidra Nath Upadhyay, SRF, as well as Dr. Ram Prakesh Srivastava, Mr Prashant Goel and Dr. Geetanjali Kannojia, respectively JRFs, PMS Phase-II in Agricultural Biotechnology also rendered their kind substantial support for collection and analysis of different Oryza sativa L. Materials. Beside other laboratory personnel and support for implementing the project by the Director Experiment Station is duly acknowledged. Ms. Alka Bameta, Research Scholar contribution for different suggestions in shaping this manuscript is required to be worth mentioning.

\section{References}

1. Buttery RG, Siefert RM, Guadagni DG, Ling LC (1971) Characterization of additional volatile components of tomato. J Agric Food Chem 19(3): 524-529.

2. Nadaf AB, Wakte KV, Zanan RL (2006) Histochemical and biochemical analysis of major aroma compound (2-acetyl-1-pyrroline) in basmati and other scented rice (Oryza sativa L.). Current science 91: 1533-1536.

3. Coffman WR, Hersera RM (1980) Rice, In: Hybridization of crop plants. American Society of Agronomy-Crop Science of America 28: 101-131.

4. Khush GS (2000) Taxonomy and origin of rice. In: Aromatic Rices, Singh RK, et al. (Eds.), Oxford and IBH Publishing Co. Pvt. Ltd, New Delhi, pp: 5-13.

5. Bose SK, Krishnamurthy K (1971) Rice, its classification and grading in India. Bull Grain Technology 9(2): 111-115.

6. Chou SL (1948) China is the place of origin of rice (in Chinese). J Rice Soc China 7: 53-54.

7. Ting Y (1957) The origin and evolution of cultivated rice in China (in Chinese with English abstract). Acta Agron Sinica 8: 243-260. 


\section{Genomics \& Gene Therapy International Journal}

8. Kovach MJ, Calingacion MN, Fitzgerald MA, McCoucha SR (2009) The origin and evolution of fragrance in rice (Oryza sativa L.). PNAS 106(34): 14444-14449.

9. Glaszmann JC (1987) Isozymes and classification of rice varieties. Theoretical and Applied Genetics 74(1): 21-30.

10. Ford-Lloyd BV, Jackson MT, Newbury HJ (1997) Molecular markers and the management of genetic resources in seed genebanks: a case study of rice. In: Callow JA, Ford-Lloyd BV, Newbury HJ, (eds.), Biotechnology and plant genetic resources: conservation and use. CAB International, Wallingford.

11. Song ZP, Xu X, Wang B, Chen JK, Lu BR (2003) Genetic diversity in the northernmost Oryza rufipogon populations estimated by SSR markers. Theor Appl Genet 107: 1492-1499.

12. Wang Z, Tanksley S (1989) Restriction fragment length polymorphism in Oryza sativa Genome 32: 1113-1118.

13. Wu KS, Tanksley SD (1993) Abundance, polymorphism and genetic mapping of microsatellites in rice. Gen Genet 241(1-2): 225-235.

14. Zeitkiewicz E, Rafalski A, Labuda D (1994) Genome fingerprinting by simple sequence repeat (SSR)anchored polymerase chain reaction amplification. Genomics 20: 176-183.

15. Virk PS, Ford-Lloyd BV, Jackson MT, Newbury HJ (1995) Use of RAPD for the study of diversity within the plant germplasm collection. Heredity 74: 170179.

16. Zhou Z, Gustafson JP (1995) Genetic variation detected by DNA fingerprinting with a rice minisatellite probe in Oryza sativa Theor. Appl Genet 91(3): 481-488.

17. Ashikawa I, Fukuta Y, Tamura K, Yagi TAD (1999) Application of AFLP technique that uses nonradioactive fluorescent primers for the detection of genetic diversity in Japanese rice cultivars and cloning of DNA sequences derived from an indica genome. Breed Sci 49: 225-231.

18. Dong NV, Subudhi PK, Luong PN, Quang VD, Quy TD, et al. (2000) Molecular mapping of a rice gene conditioning thermosensitive genic male sterility using AFLP, RFLP and SSR techniques. Theor Appl Genet 100(5): 727-734.
19. Siva R, Kumar K, Rajasekaran C (2010) Genetic diversity study of important Indian rice genotypes using biochemical and molecular markers. African Journal of Biotechnology 12(10): 1004-1009.

20. Sekhar BP, Reddy GM (1982) Amino acid profiles in some scented rice varieties. Theor Appl Genet 62(1): 35-37.

21. Ngadi N, Yahya NY (2014) Extraction of 2-Acetyl-1Pyrroline (2AP) in Pandan Leaves (Pandanus Amaryllifolius Roxb.) Via Solvent Extraction Method: Effect of Solvent. Jurnal Teknologi 67(2): 51-54.

22. Yoshihashi T, Huong NT, Inatomi H (2002) Precursors of 2-acetyl-1-pyrroline, a potent flavor compound of an aromatic rice variety. J Agric Food Chem 50(7): 2001-2004.

23. Husaini AM, Parray GA, Rather AG, Sanghera GS (2009) Performance of elite basmati rice varieties of subtropical India under temperate valley conditions of Kashmir, Genetic resources. International Rice Research Notes, pp: 0117-4185.

24. Anita Kumari, Anil Kumar, Anil Kumar Gaur (2017) Histochemical and Organolyptic Analysis of Major Aroma Compound (2-acetyl-1-pyrroline) in Kalanamak Rice Landraces and Some Basmati Rice Varieties. Cell Cellular Lif Sci J 2(2): 000112.

25. Wongpornchai S, Dumri K, Jongkaewwattana S, Siri B (2004) Effects of drying methods and storage time on the aroma and milling quality of rice (Oryza sativa L.) cv. Khao Dawk Mali 105. Food Chemistry 87: 407414.

26. Laksanalamai V, Ilangantileke S (1993) Comparison of aroma compound (2-acetyl-1-pyrroline) in leaves from pandan (Pandanus amaryllifolium) and Thai Fragrant rice (Khao dawk Mali-105). Cereak Chem 70(4): 381-384.

27. Petrov M, Danzart M, Giampaoli P, Faure J, Richard H (1996) Rice aroma analysis: discrimination between a scented and a non-scented rice. Sciences des Aliments 16(4): 347-360.

28. Pachauri V, Singh MK, Singh AK, Singh S, Shakeel NA, et al. (2010) Origin and genetic diversity of aromatic rice varieties, molecular breeding and chemical and genetic basis of rice aroma. Pl Biochem Biotechnol 19: 127-143. 


\section{Genomics \& Gene Therapy International Journal}

29. Kadam BS, Patankar VK (1938) Inheritance of aroma in rice. Bot 4: 32.

30. Jodon E (1944) The inheritance of flower fragrance and other character in rice. J Amer Soc Agron 36: 844848.

31. Amarawathi $Y$, Singh $R$, Singh AK, Singh VP, Mohapatra T, et al. (2008) Mapping of quantitative trait loci for basmati quality traits in rice. Mol Breed 21(1): 49-65.

32. Bradbury LMT, Fitzgerald TL, Henry RJ, Jin Q, Waters DLE (2005a) The gene for fragrance in rice. Plant Biotechnol J 3(3): 363-370.

33. Wanchana S, Kamolsukyunyong W, Ruengphayak S, Toojinda T, Tragoonrung S, et al. (2005) A rapid construction of a physical contig across a $4.5 \mathrm{cM}$ region for rice grain aroma facilitates marker enrichment for positional cloning. Science Asia 31: 299-306.

34. Chen S, Wu J, Yang Y, Shi W, Xu M (2006) The fgr gene responsible for rice fragrance was restricted within 69kb. Plant Sci 171(4): 505-514.

35. Singh A, Singh PK, Singh R, Pandit A, Mahato AK, et al. (2010) SNP haplotypes of the BADH1 gene and their association with aroma in rice (Oryza sativa L.) Molecular Breeding 26: 325-338.

36. Berner DK, Hoff BJ (1986) Inheritance of scent in American long grain rice. Crop Science 26(5): 876878.

37. Ahn SN, Bollich CN, Tanksley SD (1992) RFLP tagging of a gene for aroma in rice. Theor Appl Genet 84(7-8): 825-828.

38. Kishitani S, Takanami T, Suzuki M, Oikawa M, Yokoi S, et al. (2000) Compatibility of glycine betaine in rice plants: evaluation using transgenic rice plants with a gene for peroxisomal betaine aldehyde dehydrogenase from barley. Plant Cell Environ 23(1): 107-114.

39. Ishitani M, Arakawa K, Mizuno K, Kishitani S, Takabe $T$ (1993) Betaine aldehyde dehydrogenase in the gramineae: levels in leaves both betaineaccumulating and no accumulating cereal plants. Plant Cell Physiol 34: 493-495.

40. Chen S, Yang Y, Shi W, Ji Q, He F, et al. (2008) Badh2, encoding betaine aldehyde dehydrogenase, inhibits the biosynthesis of 2-acetyl-1-pyrroline, a major component in rice fragrance. Plant Cell 20(7): 18501861.

41. Bradbury LM, Gillies SA, Brushett DJ, Waters DL, Henry RJ (2008) Inactivation of an aminoaldehyde dehydrogenase is responsible for fragrance in rice. Plant Mol Biol 68: 439-449.

42. Vanavichit A, Yoshihashi T, Wanchana S, Areekit S, Saengsraku D, et al. (2005) Positional cloning of OS2AP, the aromatic gene controlling the biosynthetic switch of 2-acetyl-1-pyrroline and gamma aminobutyric acid (GABA) in rice. In 5th International Rice Genetics Conference, Manila, International Rice Research Institute, pp: 44.

43. Adams A, De Kimp N (2007) Formation of pyrazines and 2- acetyl-1-pyrroline by Bacillus cereus. Food Chem 101(3): 1230-1238.

44. Huang TC, Teng CS, Chang JL, Chuang HS, Ho CT, et al. (2008) Biosynthetic mechanism of 2-acetyl-1pyrroline and its relationship with D1-pyrroline-5carboxylic acid and methylglyoxal in aromatic rice (Oryza sativa L.) callus. Agric Food Chem 56: 73997404.

45. Yajima I, Yanai T, Nakamura M, Sakakibara H, Habu $\mathrm{T}$ (1978) Volatile Flavor Components of Cooked Rice. Agricultural and Biological Chemistry 42: 1229-1233.

46. Buttery RG, Ling LC, Mon TR (1986) Quantitative analysis of 2-acetyl-1-pyrroline in rice. J Agric Food Chem 34(1): 112-114.

47. Buttery RG, Ling LC, Juliano BG, Tumbaugh JG (1983) Cooked rice aroma and 2-acetyl-1pyrroline. J Agric Food Chem 31(4): 823-826.

48. Buttery RG, Lilng LC, Juliano BO (1982) 2-Acety-1pyrroline: An important aroma component of cooked rice. Chem Ind, pp: 958-959.

49. Widjaja RW, Craske JD, Wootton M (1996) Comparative studies on volatile components of nonfragrant and fragrant rices. Journal of the Science of Food and Agriculture 70: 151-161.

50. Wilkie K, Wootton M (2004) Flavour qualities of new Australian fragrant rice cultivars in Australian Government-Rural Industries Research and Development Corporation (RIRDC). 


\section{Genomics \& Gene Therapy International Journal}

51. Lorieux M, Petrov M, Huang N, Guiderdoni E, Ghesquiere A (1996) Aroma in rice: Genetic analysis of a quantitative Theoretical and Applied Genetics 93(7): 1145-1151.

52. Bergman CJ, Delgado JT, Bryant R, Grimm C, Cadwallader KR, et al. (2000) Rapid gas chromatographic technique for quantifying 2- acetyl1-pyrroline and hexanal in rice (Oryza sativa, L.). Cereal Chemistry 77(4): 454-458.

53. Livingstone JR, Maruo T, Yoshida I, Tarui Y, Hirooka K, et al. (2003) Purification and properties of betaine aldehyde dehydrogenase from Avenasativa. Journal of Plant Research 116(2): 133-140.

54. Rewicki D, Tressl R, Ellerbeck U, Kersten E, Burgert W, et al. (1993) Formation and synthesis of some Maillard generated aroma compounds. In: Progress in Flavour Precursors Studies, Schreier P, Winterhalter $\mathrm{P}$, (Eds.), Proceedings of the International Conference, Allured Publishing Corp: Carol Stream, Würzburg, Germany, pp: 301-314.

55. Schieberle P (1995) Quantitation of Important RoastSmelling Odorants in Popcorn by Stable Isotope Dilution Assays and Model Studies on Flavor Formation during Popping. Agric Food Chem 43(9): 2442-2448.

56. Hofmann T, Schieberle P (1998) 2-Oxopropanal, Hydroxy-2-propanone, and 1-PyrrolineImportant Intermediates in the Generation of the Roast-Smelling Food Flavor Compounds 2-Acetyl-1-pyrroline and 2Acetyltetrahydropyridine. Agric Food Chem 46(6): 2270-2277.

57. De Kimpe NG, Christian V Stevens, Marian A Keppens (1993) Synthesis of 2-acetyl-1-pyrroline, the principal rice flavor component. J Agric Food Chem 41(9): 1458-1461.

58. Duby P, Huynh-Ba (1993) European patent 0545085A1, Chemical Abstracts 119: 138068.

59. Kumar LS (1999) DNA markers in plant improvement: An overview. Biotechnology Advances 17(2-3): 143-182.

60. Xiao J, Li J, Yuan L, Tanksley SD (1995) Dominance is the major genetic basis of heterosis in rice as revealed by QTL analysis using molecular markers. Genetics 140(2): 745-754.
61. Basten CJ, Weir BS, Zeng ZB (2002) QTL cartographer Version 1.16 Department of Statistics, North Carolina State University, Raleigh, NC.

62. Wang S, Basten CJ, Zeng ZB (2010) Windows QTL Cartographer 2.5. Department of Statistics, North Carolina State University, Raleigh, NC.

63. Cho YG, McCouch SR, Kuiper M, Kang MR, Pot J, et al. (1998) Integrated map of AFLP. SSLP and RFLP markers using a recombinant inbred population of rice (Orayza saliva L.). Theor Appl Genet 97: 370-380.

64. Garland S, Lewin L, Blakeney A, Reinke A, Henry R (2000) PCR-based molecular markers for the fragrance gene in rice (Oryza sativa L.). Theor Appl Genet 101(3): 364- 371.

65. Salvi S, Tuberosa R (2005) To clone or not to clone plant QTLs: Present and future challenges. Trends Plant Sci 10: 297-304.

66. Kathiresan A, Lafitte HR, Chen J, Mansueto L, Bruskiewich R, et al. (2006) Gene expression microarray and their application in drought stress research. Field Crops Res 97: 101-110.

67. Fitzgerald MA, Hamilton NRS, Calingacion MN, Verhoeven HA, Butardo VM (2008) Is there a second fragrance gene in rice? Plant Biotechnol J 6(4): 416423.

68. Golam F, Kamilatulhusna Z, Arash N, Mohamad 0 (2014) Genetic Analysis of F1 Hybrids Derived from Aromatic (Exotic) Aromatic (Malaysian) Rice Crosses and Their Callus Induction Performance for Haploid Production. Indian Journal Science Technology 7(11): 1852-1860.

69. Jewel ZA, Patwary AK, Maniruzzaman S, Barua R, Begum SN (2011) Physico-Chemical and Genetic Analysis of Aromatic Rice (Oryza sativa) Germplasm. The Agriculturists 9(1-2): 82-88.

70. Yi M, Nwe KT, Vanavichit A, Chai-arree W, Toojinda T (2009) Marker assisted backcross breeding to improve cooking quality traits in Myanmar rice cultivar Manawthukha. Field Crops Res 113(2): 178186.

71. Yoshihashi T, Huong NT, Surojanametakul V, Tungtrakul P, Varanyanond W (2005) Effect of Storage Conditions on 2-acetyl-1-pyrroline Content in Aromatic Rice Variety, Khao Dawk Mali 105. J Food Sci 70: 34-37. 


\section{Genomics \& Gene Therapy International Journal}

72. Itani T, Tamaki M, Hayata Y, Fushimi T, Hashizume $\mathrm{K}$ (2004) Variation of 2-acetyl-1-pyrroline concentration in aromatic rice grains collected in the same region in Japan and factors affecting its concentration. Plant Production Science 7: 178-183.

73. Goufo P, Wongpornchai S, Tang X (2010) Decrease in rice aroma after application of growth regulators. Agronomy for Sustainable Development 31(2): 349359.

74. Zeng Z, Zhang H, Chen JY, Zhang T, Matsunaga R (2008) Flavor volatiles of rice during cooking analyzed by modified headspace SPME/GCMS. Cereal Chemistry 85(2): 140-145.

75. Sood BC, Siddiq EA (1978) A rapid technique for scent determination in rice. Indian Journal of Genetics and Plant Breeding 38(2): 268-275.

76. Cordeiro GM, Christopher MJ, Henry RJ, Reinke RF (2002) Identification of microsatellite markers for fragrance in rice by analysis of therice genome sequence. Molecular Breeding 9(4): 245-250.

77. Jin $Q$, Waters D, Cordeiro GM, Henry RJ, Reinke RF (2003) A single nucleotide polymorphism (SNP) marker linked to the fragrance gene in rice (Oryza sativa. L.). Plant Science 165(2): 359-364.

78. Tragoonrung S, Sheng JQ, Vanavichit A (1996) Tagging an aromatic gene in lowland rice using bulk segregant analysis. Rice Genetics, pp: 613-618.

79. Tanchotikul U, Hsieh TCY (1991) An improved method for quantification of 2-acetyl-1-pyrroline, a "popcorn"-like aroma, in aromatic rice by high resolution gas chromatography/mass spectrometry/selected ion monitoring. Agrie Food Chem 39: 944-947.

80. Arthur CL, Pawliszyn J (1990) Solid phase microextraction with thermal desorption using fused silica optical fibers. Analytical chemistry 62(19): 2145-2148.

81. Grimm CC, Bergman C, Delgado JT, Bryant R (2001) Screening for 2- acetyl-1-pyrroline in the headspace of rice using SPME/GC-MS. Journal of Agricultural and Food Chemistry 49(1): 245-249.

82. Weckwerth W (2003) Metabolomics in systems biology. Annual Review in Plant Biology 54: 669-689.
83. Oksman-Caldentey KM, Saito K (2005) Integrating genomics and metabolomics for engineering plant metabolic pathways. Current Opinion in Biotechnology 16: 174-179.

84. Mendes P (2006) Metabolomics and the challenge ahead. Briefings in Bioinformatics 7(2): 127.

85. German JB, Roberts MA, Fay L, Watkins SM (2002) Metabolomics and Individual metabolic assessment: The next great challenge for nutrition. Journal of Nutrition 132(9): 2486-2487.

86. Tiller PR, Yu S, Castro-Perez J, Fillgrove KL, Baillie TA (2008) Highthroughput, acurate mass liquid chromatography/tandem mass spectrometry on a quadrupole time-of-flight system as a "first line" approach for metabolite identification studies. Rapid Communication in Mass Spectrometry 22: 10531061.

87. Oliver JD, Nokolau B, Wurtele ES (2002) Functional genomics: Highthroughput mRNA, protein, and Metabolite analyses. Metabolic Enginerring 4: 98-106.

88. Villas-Boas SG, Moxley JF, Akesson M, Stephanopoulos G, Nielsen J (2005) High-throughput metabolic analysis: the missing link in integrated functional genomics of yeasts. Biochem J 388(2): 669-677.

89. Zamboni FN, Sauer U (2004) High-throughput metabolic flux analysis based on gas chromatorgraphy-mass spectrometry derived 13C constraints. Analytical Biochemistry 325: 308-316.

90. Brocke AV, Nicholson G, Bayer E (2001) Recent advances in capillary electrophoresis/electrospraymass spectrometry. Electrophoresis 22(7): 12511266.

91. Dettmer K, Aronov PA, Hammock BD (2007) Mass spectrometry-based metabolomics. Mass Spectrometry Review 26(1): 51-78.

92. Katajamaa M, Oresic M (2007) Data processing for mass spectrometry based metabolomics. Journal of Chromatography A 1158: 318-328.

93. Van Beek TA, Montoro P (2009) Chemical analysis and quality control of Ginkgo biloba leaves, extracts, and phytopharmaceuticals. J Chromatogr A 1216: 2002-2032.

94. Tohge T, Fernie AR (2010) Combining genetic diversity, informatics and metabolomics to facilitate 


\section{Genomics \& Gene Therapy International Journal}

annotation of plant gene function. Nature Protocol 5: 1210-1227.

95. Saito K, Masuda F (2010) Metabolomics for functional genomics, system biology, and biotechnology. Rev Plant Biol 61: 463-489.

96. Schauer N, Fernie AR (2006) Plant metabolomics: Towards biological function and mechanism. Trends in Plant Science 11: 508-516.

97. Schwab W (2003) Metabolome diversity: too few genes, too many metabolites? 62: 837-849.

98. Maury S, Geoffroy P, Legrand M (1999) Tobacco Omethyltransferase involved in phenylpropanoid metabolism. The different caffeoylcoenzyme A/5hydroxyferuloyl-Coenzyme A3/5-OMethyltransferase and caffeic acid/ 5-hydroxyferulic acid 3/5OMethyltransferase classes have distinct substrate specificities and expression patterns. Plant Physiology 121: 215-224.

99. Warner SJ, Gill A, Draper J (1994) The developmental expression of the asparagus intracellular PR protein (AoPR1) genes correlates with sites of phenylpropanoid biosynthesis. The plant Journal 6: 31-43.

100. Hirai MY, Klein M, Fujikawa Y, Yano M, Goodenowe DB, et al. (2005) Elucidation of gene-to-gene and metaboliteto- gene networks in Arabidopsis by integration of metabolomics and transcriptomics. Journal of Biological Chemistry 280(27): 2559025595 .

101. Saito K, Dixon RA, Willmitzer L (2006) Plant Metabolomics. Biotechnology in Agriculture and Forestry.

102. Fernie AR, Geigenberger P, Stitt M (2005) Flux an important, but neglected, component of functional genomics. Current Opinion in Plant Biology 8(2): 174182.

103. Hall RD (2006) Plant metabolomics: from holistic hope, to hype, to hot topic. New Phytologist 169(3): 453-468.

104. Krishnan P, Kruger NJ, Ratcliffe RG (2005) Metabolite fingerprinting and profiling in plants using NMR. Journal of Experimental Botany 56: 255-265.

105. Dunn WB (2008) Current trends and future requirements for the mass spectrometric investigation of microbial, mammalian and plant metabolomes. Physical Biology 5(1): 11001.

106. Lisec J, Schauer N, Kopka J, Willmitzer L, Fernie AR (2006) Gas chromatography mass spectrometry based metabolite profiling in plants. Nature Protocol 1(1): 387-396.

107. Chikayama E, Sekiyama Y, Okamoto M, Nakanishi Y, Tsuboi Y, et al. (2010) Statistical indices for simultaneous large-scale metabolite detections for a single NMR spectrum. Analytical Chemistry 82(5): 1653-1658.

108. Codrea MC, Jimenez CR, Heringa J, Marchiori E (2007) Tools for computational processing of LC-MS datasets: a user's perspective. Computer Methods and Programs Biomedicine 86(3): 281-290.

109. Tokimatsu T, Sakurai N, Suzuki H, Ohta H, Nishitani $\mathrm{K}$, et al. (2005) KaPPA-View. A Web-Based Analysis Tool for Integration of Transcript and Metabolite Data on Plant Metabolic Pathway Maps. Plant Physiology 138(3): 1289-1300.

110. Moco S, Bino RJ, Vorst O, Verhoeven HA, Groot JD, et al. (2006) A Liquid Chromatography-Mass Spectrometry-Based Metabolome Database for Tomato. Plant Physiology 141: 1205-1218.

111. Krieger CJ, Zhang P, Lukas A, Wang MA, Paley S, et al. (2004) MetaCyc: a multi organism database of metabolic pathways and enzymes. Nucleic Acid Research 32: 438-442.

112. Wagner C, Sefkow M, Kopka J (2003) Construction and application of a mass spectral and retention time index database generated from plant GC/EI-TOF-MS metabolite profiles 62: 887-900.

113. Zhang P, Foerster H, Tissier CP, Mueller L, Paley S, et al. (2005) MetaCyc and AraCyc Metabolic Pathway Databases for Plant Research. Plant Physiology 138: 27-237.

114. Sumner LW, Mendes P, Dixon RA (2003) Plant metabolomics: large-scale phytochemistry in the functional genomics era. Phytochemistry 62: 817836.

115. Morgan JA, Rhodes D (2002) Mathematical Modeling of Plant Metabolic Pathways. Metabolic Engineering 4(1): 80-89. 


\section{Genomics \& Gene Therapy International Journal}

116. Gombert AK, Nielsen J (2000) Mathematical modeling of metabolism. Current Opinion in Biotechnology 11(2): 180-186.

117. Bailey JE (1997) Metabolic consequences of phosphotransferase system (PTS) mutation in a phenylalanine producing recombinant Escherichia coli. Biotechnology Progress 13(6): 768-775.

118. Mott KA, Woodrow IE (2000) Modeling the role of Rubisco activase in limiting non-steady-state photosynthesis. Journal of Experimental Botany 51: 399-406.

119. Gaur AK (2017) Bioactive Secondary Metabolites Associated Genes from High Value Rare Medicinal Plants are Panacea for Metabolic Engineering. Genomics \& Gene Therapy International Journal 1(1): $1-2$.

120. Bhattacharjee P, Singhal RS, Kulkarni PR (2002) Basmati rice: a review. Int. J Food Sci Technol 37: 112.

121. Bligh HFJ, Blackhall NW, Edwards KJ, McClung AM (1999) Using amplied fragment length polymorphisms and simple sequence length polymorphisms to identify cultivars of brown and white milled rice. Crop science 39(6): 1715-1721

122. Bryant RJ, McClung AM (2011) Volatile profiles of aromatic and nonaromatic rice cultivars using SPME/GC-MS. Food Chemistry 124(2): 501-513.

123. Huang FS, Sun ZX, Hu PS, Tang SQ (1998) Present situations and prospects for the research on rice grain quality forming. Chinese J Rice Sci 12(3): 172176.

124. Khush GS (1971) Rice breeding for disease and insect resistance at IRRI. Oryza 8(2): 111-119.

125. Lestari AP, Abdullah B, Junaedi A, Aswidinnoor H (2011) Performance of Grain Quality and Aroma of Aromatic New Plant Type Promising Rice Lines. Indonesian J Agric Sci 12(2): 83-93.

126. Sakthivel K, Sundaram R, Shobha Rani N, Balachandran S, Neeraja C (2009b) Genetic and molecular basis of fragrance in rice Adv. Biotechnology Advances 27(4): 468-473. 